\title{
Mechanical Behaviors of Composite Leaf Springs with Additive of Carbon Nanotubes and Chitosan
}

\author{
Hasan Çallığlu ${ }^{1 *}$, Furkan Kavla ${ }^{2}$ \\ ${ }^{1}$ Mekatronik Mühendisliği / Teknoloji Fakültesi, Pamukkale Ünivesitesi, Türkiye (ORCID: 0000-0002-4598-7975) \\ 2 Otomotiv Mühendisliği / Fen Bilimleri Enstitüsü, Pamukkale Üniversitesi, Türkiye (ORCID: 0000-0002-6426-6911)
}

(This publication has been presented orally at HORA congress.)

(First received 1 August 2019 and in final form 25 October 2019)

(DOI: $10.31590 /$ ejosat.638084)

ATIF/REFERENCE: Çallığlu, H. \& Kavla, F. (2019). Mechanical Behaviors of Composite Leaf Springs with Additive of Carbon Nanotubes and Chitosan. European Journal of Science and Technology, (Special Issue), 270-283.

\begin{abstract}
Suspension systems are automotive parts which absorb sudden impacts caused by roads and providing comfort have an essential role in the automotive sector. Reducing weight is a fundamental way to decrease energy consumption and emission release. This study establishes improvement conditions by analysing layered composite springs which have different compositions and different support angles under various weights. Ten plaques which made with various compositions chitosan and carbon nanotubes, also one-way glass fiber/epoxy composite plaques with prepreg method and one unalloyed plaque were produced. Standard samples were extracted by water jet and pull\&push test were applied to identify mechanical properties. Five standard samples were used to identify each mechanical property. Mechanical properties of samples with different compositions were compared.

Identified mechanical properties were used as material properties at the ANSYS ACP PRE\&POST analysis program. Composite spring thicknes were $12 \mathrm{~mm}$ and it is composed of 60 layers. Static analysis of composite springs modelled with five different layer orders was done by applying $1000 \mathrm{~N}, 2000 \mathrm{~N}, 3000 \mathrm{~N}$ and $3750 \mathrm{~N}$ force. Collapse, stress and shape changes of composite springs were examined at static analyses.

Analysis show that unalloyed composite leaf spring is more resistant than its counterparts. When Layer Order $1(\mathrm{TD} 1)$ [ $\left.\left.0^{\circ}\right)\right] 60$ with the same direction for fiber and horizontal axis of composite leaf spring is compared with others, it is seen that composite spring with TD1 is more rigid against bending. Damage analysis was done with ACP POST program according to Tsai-Wu and Hashin standards and it is seen that end points of springs were mostly damaged. Most damaged one is the TD5 leaf spring with $\left[\left(0^{\circ}{ }_{5} / 90^{\circ}{ }_{5} / 45^{\circ}{ }_{10} /-45^{\circ}{ }_{10}\right)\right]_{\mathrm{s}}$ layer order under $3750 \mathrm{~N}$ according to Tsai-Wu standard. In addition to that, composite leaf springs were $\% 49,84$ lighter than mostly used one leaf steel counterparts.
\end{abstract}

\section{Kitosan/Karbon Nanotüp Katkili Kompozit Yaprak Yaylarin Mekanik Davranişlari}

$\ddot{\mathbf{O} z}$

Günümüz otomotiv sektöründe hayati öneme sahip süspansiyon sistemleri, yol koşullarından kaynaklanan ani şok darbelerini sönümleyen ve konfor sağlayan otomotiv parçalarıdır. Enerji tüketimini azaltmak ve emisyon salınımını düşürmek için ağırlıktan kazanç otomotiv sektörü için hayati bir öneme sahiptir. Bu nedenle bu çalışmada, ağırlıkça farklı katkı oranlarına ve farklı takviye açılarına sahip tabakalı kompozit yaylar değişken yükler altında nümerik olarak analiz edilerek uygun iyileştirme şartları tespit edilmeye çalışılmıştır. Kitosan, karbonnanotüp ve bunların karışımından oluşan farklı katkı oranlarında, tek yönlü cam elyaf/epoksi kompozit plakalar prepreg yöntemi ile biri katkısız olmak üzere on adet plaka imal edilmiştir. Mekanik özelliklerinin tespit edilmesi için su jeti ile plakalardan standart numuneler çıkartılmış ve çekme ve basma testleri icra edilmiştir. Her mekanik özelliğin tespiti için beş standart numune kullanılmıştır. Farklı katkı oranlarına sahip numunelerin mekanik özellikleri birbirleriyle kıyaslanmıştır.

Elde edilen mekanik özellikler, ANSYS ACP PRE\&POST analiz programında malzeme özellikleri olarak kullanılmıştır. Kompozit yay kalınlığı 12 mm olup 60 tabakadan oluşmaktadır. Beş farklı tabaka diziliminde modellenen kompozit yaylara 1000 N, 2000 N, 3000

\footnotetext{
* Corresponding Author: Mekatronik Mühendisliği / Teknoloji Fakültesi, Pamukkale Ünivesitesi, Türkiye, ORCID: 0000-0002-4598-7975, hcallioglu@pau.edu.tr
} 
$\mathrm{N}$ ve $3750 \mathrm{~N}$ kuvvet uygulanarak statik analizleri yapılmıştır. Statik analizlerde kompozit yayların çökmesi, yayda oluşan normal gerilme ve şekil değiştirmeler incelenmiştir.

Analizler sonucunda katkısız kompozit yaprak yayın katkılı muadillerine göre daha mukavemetli olduğu tespit edilmiştir. Fiber yönü ile kompozit yaprak yayın yatay ekseni aynı doğrultuda seçilmiş olan Tabaka Düzeni 1 (TD1) $\left[\left(0^{\circ}\right)\right]_{60}$ ile diğer tabaka dizilimleri kıyaslandığında TD1'li kompozit yayın eğilmeye karşı daha rijit olduğu tespit edilmiștir. ACP POST programıyla Tsai-Wu ve Hashin kriterlerine göre hasar analizleri yapılarak en çok deformasyonun yayın uç noktalarında meydana geldiği görülmüştür. En büyük hasar miktarı $3750 \mathrm{~N}$ kuvvet altındaki $\left[\left(0^{\circ} / 90^{\circ} / 45^{\circ}{ }_{10} /-45^{\circ}{ }_{10}\right)\right]_{\mathrm{s}}$ tabaka dizilimli TD5 yaprak yayında Tsai-Wu kriterine göre olmuştur. Ayrıca kompozit yaprak yaylar, günümüzde kullanılan aynı ebatlı, tek yapraklı çelik muadili ile kıyaslandığında, \%49,84 daha hafif olmaktadır.

Anahtar Kelimeler: Kompozit Yaprak Yay 1, Karbon Nanotüp 2, Kitosan 3, Cam Fiber 4.

\section{Introduction / Giriş}

Küresel çalışmalar ve sürekli güncellenen teknoloji sistemleri daha iyi olanı üretme konusundaki çabaları desteklemektedir. Teknoloji günümüzde insanın çevreye verdiği zararı telafi etme konusunda arayışa girmiştir. Bu arayışların 1şığında otomotiv sektörü emisyon salınımlarını azaltma konusunda büyük yatıımlar yapmaya devam etmektedir. Bu yatııımlar araçların yakıt sarfiyatını da azaltarak doğal kaynakların tükenmesini engellemeyi hedeflemektedir. Bu hususta en önemli hedefler alternatif yakıtlar ve hafifliktir. Hafiflik kazanımı yanında güvenlikten ödün verilemeyeceği için alternatif malzeme arayışları başlamıştır [1]. Kompozit malzemeler gerek hafiflik gerek sağlamlıklarından dolayı yoğun miktarda kullanılmaktadır. Çalışmamızın ana konusu olan yaprak yaylar, şaside bulunan ve yoldaki bozukluklardan dolayı meydana gelen doğrusal titreşimleri absorbe etmeye yarayan otomobil parçalarıdır.

Meatto ve Pilpel (1999) tarafindan yapılan çalışmada standart çok yapraklı çelik yaprak yay ile Hibrit tek katlı yaprak yay karşılaştırılmıştır. Yapılan çalışmalarda hibrit yayın mukavemet özellikleri çelik yay ile kıyaslanarak özellikle otomobiller ve hafif ticari araçlarda kullanılması durumunda elde edilecek avantajlar irdelenmiştir. [2]

Shokrieh and Rezaei (2003) yaptıkları çalı̧̧mada çelik yaprak yay ile kompozitten imal edilmiş yaprak yayları kıyaslamıştır. Yapılan çalışmalar sonucunda daha az gerilme oluştuğu fakat daha fazla doğal frekans meydana geldiği gözlemlenmiştir. \% 80 oranında hafiflik sağlanmıştır. [3]

Patunkar ve Dolas (2011) yaptıkları çalışmada ağırlık avantajları ve dayanıklılıkları bakımından kompozit ve çelik yaprak yayları irdelemiştir. Sonuçlara göre kompozit yaprak yayların çelik yaylara göre çökme miktarı daha azdır. Yapılan tartımlar sonucu ağırlıkta $\% 84,40$ oranında hafiflik sağlanmıştır. [4]

Kumar ve Teja (2012) yaptıkları çalışmada çelik yaprak yayla E cam fiberden imal edilmiş epoxy komozit yaprak yayı kıyaslamıştır. Analizler sonucunda çökme miktarlarının yakın olduğu ve kompozit yayın \%60,48 daha hafif olduğu tespit edilmiştir. [5]

Venkatesan ve Devaraj (2012) yaptıkları çalışmada kompozit yaprak yay ile çelik yaprak yayı birbiri ile kıyaslamıştır. Yapılan analizler sonucunda kompozit yayın \%67,35 daha az gerilme, $\% 64,95$ daha sert ve $\% 126,98$ daha fazla doğal frekans1 olduğu tespit edilmiştir. Kompozit yaprak yay çelik yaydan \%76,4 daha hafif olduğu tespit edilmiştir. [6]

Narayana (2012) yaptığı çalışmada tek parça kompozit yaprak yayın dizayn ve analizini irdelemiştir. Analizler sonucunda kompozit yayda meydan gelen çökme miktarı ve gerilmeler kabul edilebilir seviyede ve iyi bir güvenlik faktöründe olduğu tespit edilmiştir. Katmanları oluştururken fiber yönünün yaprak yayın boylamasına olması yaya sağlamlık kattığı tespit edilmiştir. Optimum katman dizisi yaprak yayın boylamı boyunca ve tek yönlü şekilde olması gerektiği tespit edilmiştir. Ağırlık ta hafifleme yönünden E cam fiber epoxy kompozit yaprak yay çelik yaprak yay göre \%72,4 oranında avantajlıdır. [7]

Saini vd. (2013) yaptıkları çalışmada hafiflik ve sağlamlığı arttırmak adına çelik yaprak yay yerine kompozit yaprak yay kullanımı üzerinde çalışmışlardır. E cam fiberden imal edilmiş epoxy kompozit yaprak yayın yanında, karbon epoxy ve grafit epoxy kullanılarak üretilmiş kompozit yayların çelik yaprak yayla kıyaslanması gözlemlenmiştir. Çalışmanın ana konusu olan ağırlık hafifleme konusu sirasıyla E cam fiber \%81,22, \%91,95 grafit epoxy ve \%90,51 karbon epoxy die görülmektedir. [8]

Gopalakrishnan vd. (2017) yaptıkları çalışmada E cam fiber, Karbon epoxy ve grafit epoxy den 3 farklı yaprak yay imal etmişlerdir. Üretilen kompozit yaylar vakum yöntemi ile üretilmiştir. Sonuçlar irdelendiğin de yaprak yayın kumaş tipi yayın sertliğine oldukça etki etmektedir. Young modülü farkları ile bu gözlemlenebilmektedir. [9]

Thippesh (2018) yaptığı çalışmada hibrit kompozit yayın çökme, hafiflik ve dayanıklılık parametreleri irdelenmiştir. Kompozit yayın yapılan tek noktadan basma testinde çelik yaya göre daha az çökme miktarının olduğu gözlemlenmiştir. Kompozit yay çelik yayla kıyaslandığında \%80 e yakın hafiflik sağlamıştır. 3 noktada eğme testinde 7,7 kN kuvvet altında daha az eğilme daha az çökme olduğu tespit edilmiştir. [10]

\section{Material and Method / Materyal ve Yöntem}




\subsection{Kompozit Plakaların Hazırlanması ve Mekanik Testleri / Preparing and Mechanical Tests of Composite Plates}

Katkılı kompozit plakalar, F-RES 21 epoxy reçine, tek eksenli cam kumaş ve ağırlıkça farklı oranlarda Kitosan (K) ve Karbon nanotüp (KNT) dolgu malzemeleri kullanılarak imal edilmişlerdir. K için dolgu oranları \%1 artış ile \% \%'den \%3'e kadar iken KNT için ise $\% 0,1$ artış ile $\% 0,1$ ve $\% 0,3$ aralığındadır. Hibrit dolgu oranı ise $\% 1 \mathrm{~K}-\% 0,3 \mathrm{KNT}, \% 2 \mathrm{~K}-\% 0,3 \mathrm{KNT}$ ve $\% 3 \mathrm{~K}-\% 0,3 \mathrm{KNT}$ 'dir. Katkısız kompozitlerin mekanik özellikleri ile katkılı kompozitlerin mekanik özelliklerini karşılaştırmak için farklı oranlarda katkılı 10 adet kompozit plaka imal edilmiştir.

Dolgu malzemeleri, \%88 deasitilatlı, yüksek yoğunluklu, 1-2 $\mu$ m tanecik boyutlu karides kabuğundan çıkartılmış kitosan (SigmaAldrich, USA) ve küçük çok duvarlı karbon nanotüp (KNT) (S-MWCNT-OH) (Ege nanotek, Turkey). KNT \%98 saflığa, ağırlıkça $\% 1.76$-OH içeriğine, $10-20 \mathrm{~nm}$ dış çapa, 5-1- nm iç çapa ve $0,5-2,0$ boya sahiptir.

Tek eksenli cam kumaşlar 330gr $/ \mathrm{m}^{2}$ alansal ağırlığa $\left(0^{\circ}\right.$ doğrultusunda 1200 tex cam fibere, $90^{\circ}$ doğrultusunda 68 tex cam fibere ve 76 dtex dikiş fiberine sahiptir).

Solvent tipli prepreg reçine F-RES 21 (Fibermak Kompozit, Türkiye) matrix olarak kullanmıştır. Bu reçine düşük viskoziteye ve yüksek fiber ıslatma özelliğine sahiptir ve bunlara ek olarak $90^{\circ} \mathrm{C}$ den $150{ }^{\circ} \mathrm{C}$ ye kadar geniş bir kürleme aralığına sahiptir. Sertleştirici olarak F-HARD 22 (Fibermak Kompozit, Türkiye) kullanılmıştır. Reçine ve sertleştirici olarak ağırlıkça karıştırma oranı 21/100'dür. Jelleştirme süreci $80^{\circ} \mathrm{C}^{\prime}$ de $30-60$ dakikadır.

Dolgular ultrasonik karıştırma işleminde yapısal olarak birlikte olma eğiliminde oldukları için epoksi reçine içine eklenen dolgular, bir ultrasonik karıştırıcı (Hielscher Ultrasound Technology UP400S, Almanya) ile epoksi reçine içerisinde homojen olarak dağıtılmıştır. Topaklanan dolgular, ses dalgaları ile epoksi reçine içerisinde dağıtılmış ve ayrılmıştır. Karıştırma esnasında oluşan 1sı reçine içerisindeki dolguların homojen dağılımını engellemektedir. Bu nedenle, karıştırmada oluşan 1Sı soğuk sulu bir sirkülatör (Labo SM3, Türkiye) kullanılarak önlenmiştir ve böylece, dolguların homojen bir dağılımda olması sağlanmıştır. Karıştırma işlemi esnasında, dolgulu reçinelerin sıcaklıkları $45^{\circ} \mathrm{C}^{\prime}$ yi geçmeyecek şekilde Şekil 1 de görüldüğü üzere isıölçerle kontrol altında tutulmuştur. Bu nedenle, Şekil 2 de görüldüğü gibi karıştırma işlemi 15 dakika karıştırma, 5 dakika bekleme ve sonra tekrar 15 dakika karıştırma şeklinde uygulanmıştır. Ultrasonik karıştırıcının Saykıl değeri: 1, Amplitude: \%65 olarak ayarlanmıştır.

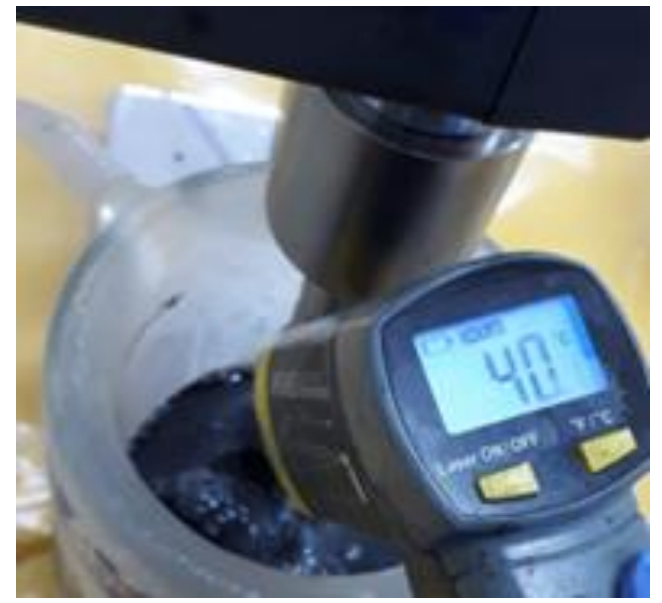

Şekil 1. Karıştırma esnasında isıölçerle kontrol

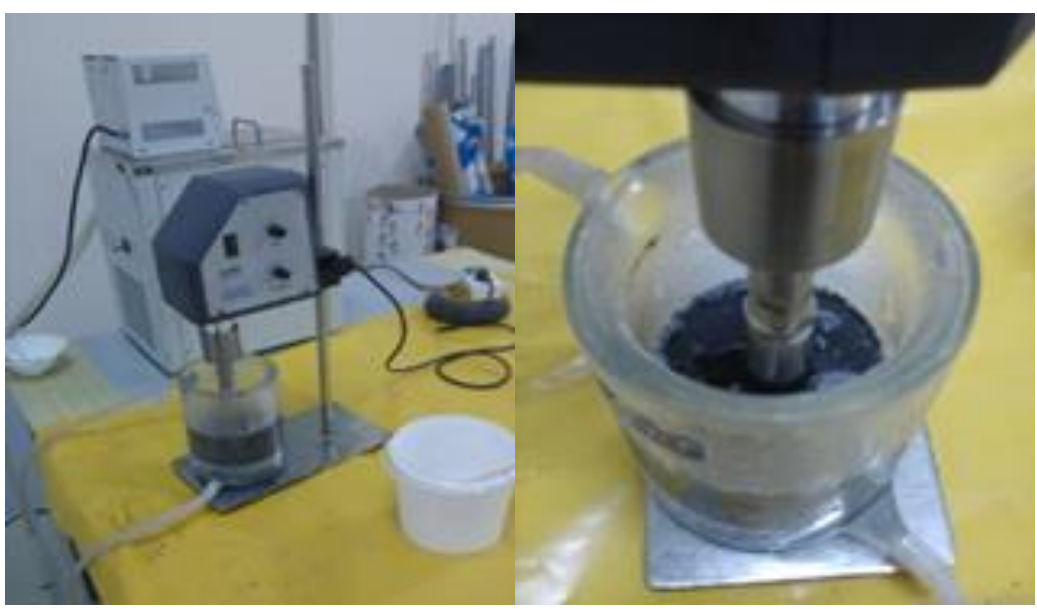

Şekil 2. Soğutma ve karıştırma işlemleri.

Altına silikonlu kâğıt konan cam fiber kumaşlar 1250 mm x 1250 mm ebatlarında kesilerek masa üzerine Şekil 3 de görüldüğü gibi serilmiştir. Cam fiber kumaşlara reçineler el yatırması yöntemi ile sürülmüştür ve böylece prepregler oluşturulmuştur. Şekil 4 te reçine sürülmüş kumaş görülmektedir. 


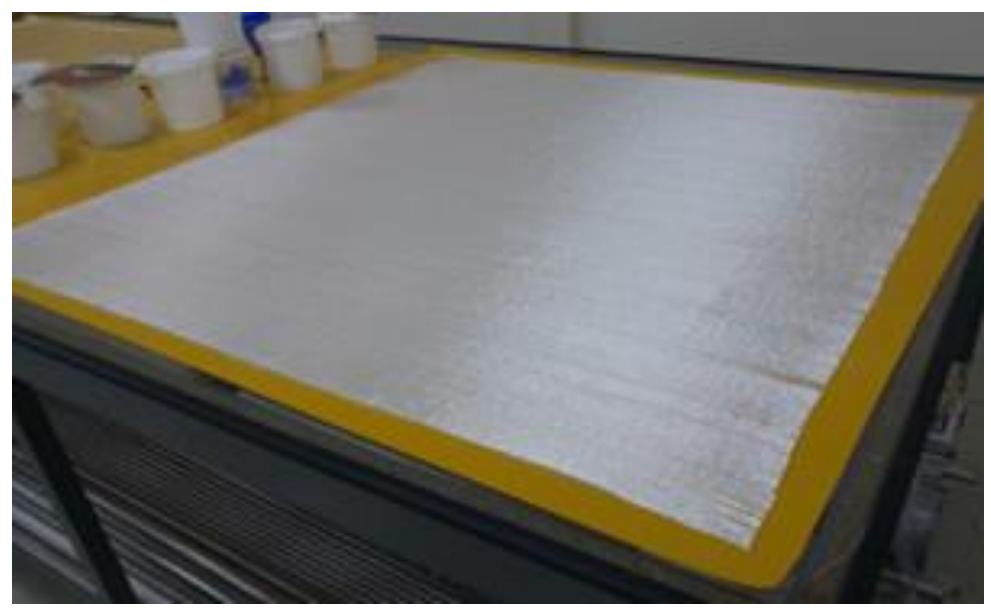

Şekil 3. Cam fiber kumaşın serilmesi

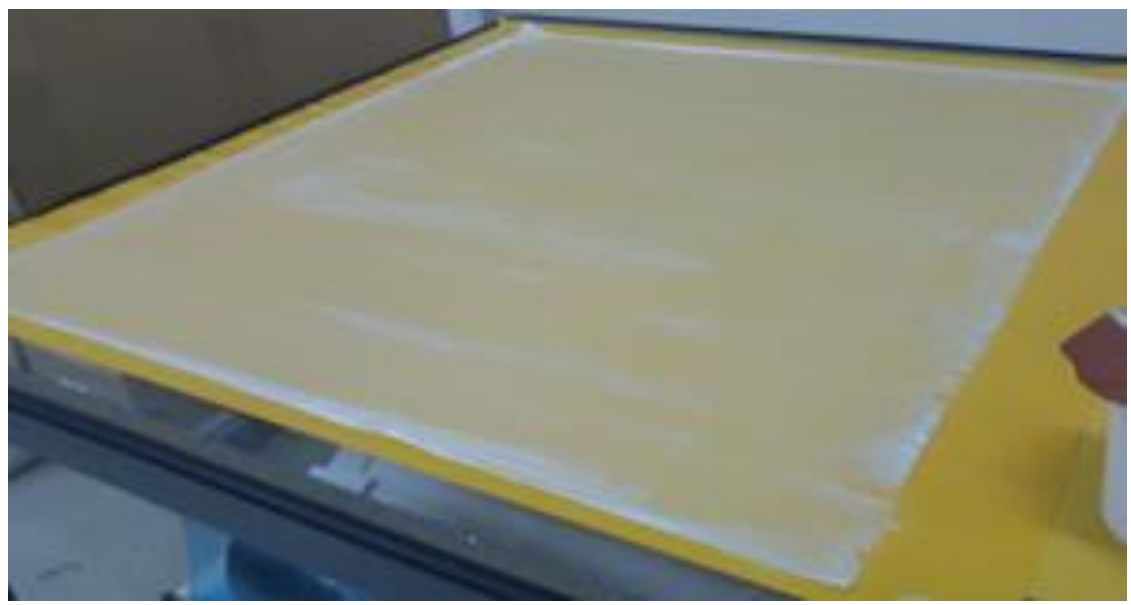

Şekil 4. Cam fiber kumaşa reçine sürülmesi

Hazırlanan prepregler 5 gün boyunca oda sıcaklığında tutulduktan sonra $400 \mathrm{~mm}$ x $400 \mathrm{~mm}$ boyutlarında kesilmiştir. Kesilen prepregler kâğıtlardan ayrıldıktan sonra aynı fiber doğrultularında denk gelecek şekilde üst üste $2 \mathrm{~mm}$ kalınlık elde edecek şekilde dizilip pres altında 1 saat $120^{\circ} \mathrm{C}$ de 6 bar basınçta kürlenmiştir. Ardından plakalar soğumaya bırakılmıştır. Soğuyan plakalar kullanıma hazır hale gelmiştir.

Plakaların mekanik testlerini icra etmek için ASTM (American Society for Testing and Materials) standartları incelenerek uygun testler belirlenmiştir. Numuneler su jeti ile kesilmiştir. Numune boyutları Şekil 5 te gösterilmektedir.

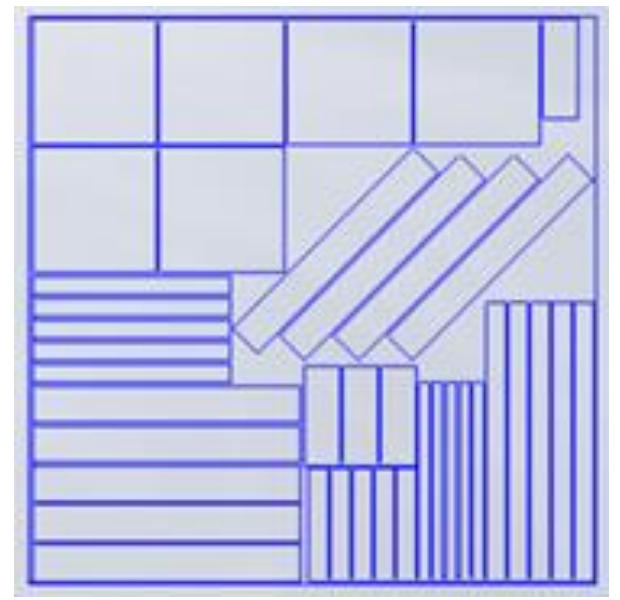

Şekil 5. Su jeti ile kesilecek olan numune boyutlart

İlk olarak elastite modülü ve kopma mukavemetini belirlemek için ASTM D3039-76 test standartlarına uygun şekilde numune kesilmiştir. Numunenin boyutları Şekil 6 da gösterilmektedir. 


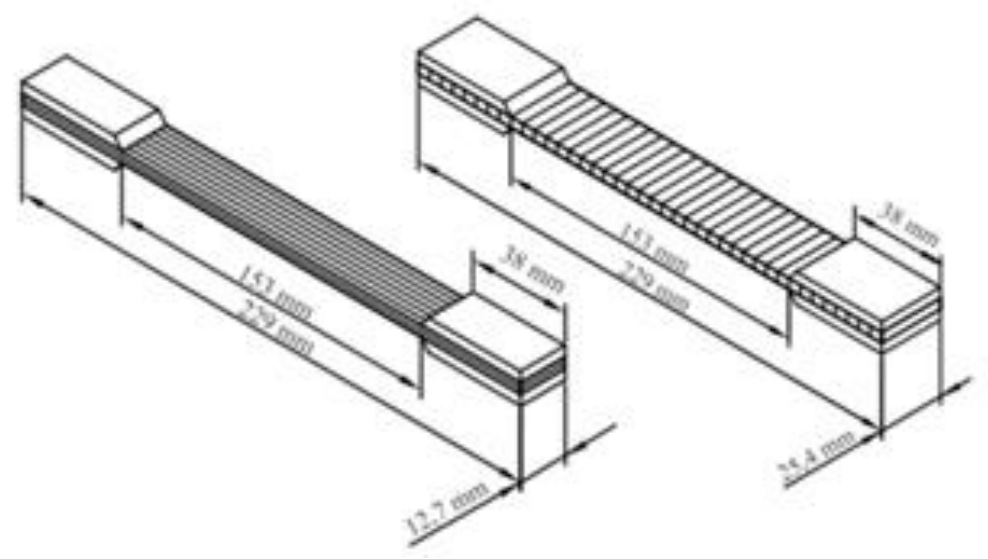

Şekil 6. ASTM D3039-76 çekme numunesi [11]

Ardından ASTM D3410-87 standartlarına uygun şekilde basma numunesi hazırlanmıştır. Hazırlanan numune boyutları Şekil 7 de gösterilmiştir
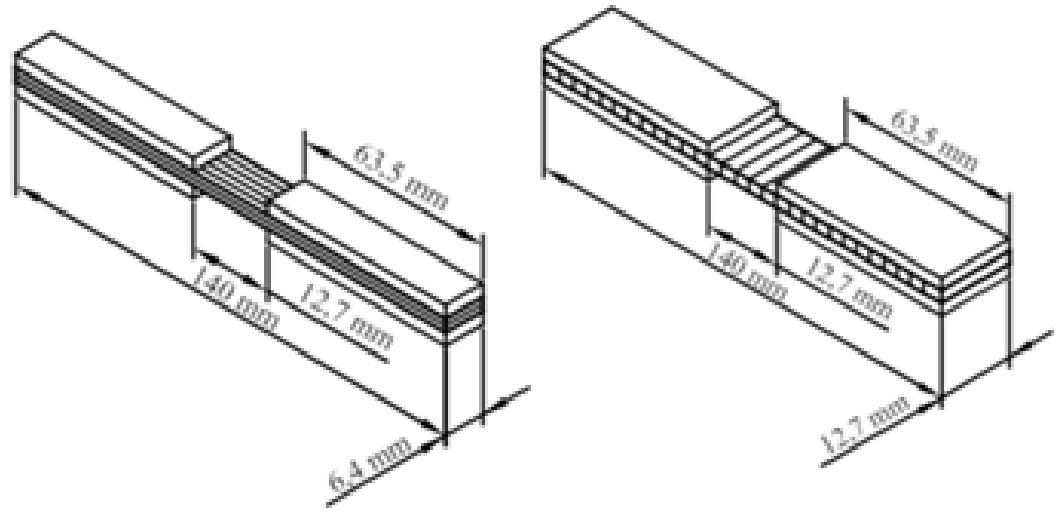

Şekil 7. ASTM D3410-87 basma numunesi [11]

Son olarak kayma modülü ve tabakalar arası kayma mukavemetinin belirlenebilmesi için numuneler hazırlanmıştır. ASTM D384679 a hazırlanmış olan tabakalararası kayma mukavemeti testi çentikli numunesi Şekil 8 de gösterilmiş̧ir.

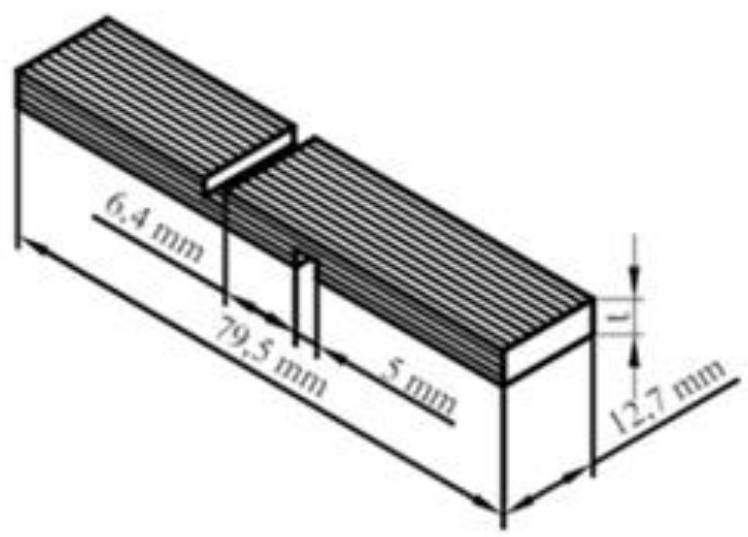

Şekil 8. ASTM D3846-79 test numunesi [11]

Mekanik testler oda sıcaklığında ve $1 \mathrm{~mm} / \mathrm{dk}$ hızla uygulanmıştır. Katkılı ve katkısız 10 adet plakaya ait mekanik özellikler Tablo 1 de verilmiştir. Mekanik testler sonucu elde edilen farklı oranlarda kitosan, karbon nanotüp, kitosan+karbon nanotüp (hibrit) katk1lı kompozitlerin fiber doğrultusundaki (1) elastisite modüllerinin değișimleri Şekil 9 da gösterilmiștir. Grafik incelendiğinde katkısız kompozit plakanın en yüksek elastisite modülüne sahip olduğu görülmektedir. Ayrıca \%1 kitosan katkılı plakanın en yüksek katkılı kompozitler arasında ki değeri verdiği grafikten görülebilmektedir. Ayrıca karbon nanotüp miktarının artması ile elastisite modülünün de arttığı görülmektedir. Hibrit katkılı kompozit incelendiğinde katk1 oranı arttıkça elastite modülünün azaldığı grafikten tespit edilmiştir. 
European Journal of Science and Technology

\begin{tabular}{|c|c|c|c|c|c|c|c|c|c|c|}
\hline & P1 & P2 & P3 & P4 & P5 & P6 & P7 & P8 & P9 & P10 \\
\hline $\begin{array}{c}E_{l} \\
(M P a)\end{array}$ & 42400 & 38200 & 31665 & 36735 & 33540 & 37065 & 36905 & 35060 & 32360 & 31868 \\
\hline $\begin{array}{c}E_{2} \\
(M P a)\end{array}$ & 13984 & 13395 & 13090 & 12590 & 14540 & 15265 & 13730 & 9934 & 10590 & 11440 \\
\hline $\begin{array}{c}G_{I 2} \\
(M P a)\end{array}$ & 3985 & 3249 & 3687 & 3879 & 3064 & 3722 & 3251 & 3535 & 3193 & 3100 \\
\hline$v_{l 2}$ & 0,239 & 0,241 & 0,247 & 0,249 & 0,247 & 0,247 & 0,248 & 0,246 & 0,247 & 0,252 \\
\hline $\begin{array}{c}X_{t} \\
(M P a)\end{array}$ & 698 & 673 & 583 & 621 & 552 & 590 & 600 & 629 & 533 & 538 \\
\hline $\begin{array}{c}X_{c} \\
(M P a)\end{array}$ & 618 & 633 & 614 & 608 & 596 & 650 & 568 & 684 & 638 & 521 \\
\hline $\begin{array}{c}Y_{t} \\
(M P a)\end{array}$ & 92 & 91 & 81 & 86 & 96 & 90 & 107 & 89 & 86 & 84 \\
\hline $\begin{array}{c}Y_{c} \\
(M P a)\end{array}$ & 200 & 107 & 136 & 171 & 190 & 157 & 212 & 160 & 167 & 168 \\
\hline $\begin{array}{c}S_{i} \\
(M P a)\end{array}$ & 18,62 & 12,84 & 10,21 & 12,9 & 18,3 & 18,4 & 6,15 & 4,54 & 4,2 & 4,52 \\
\hline
\end{tabular}

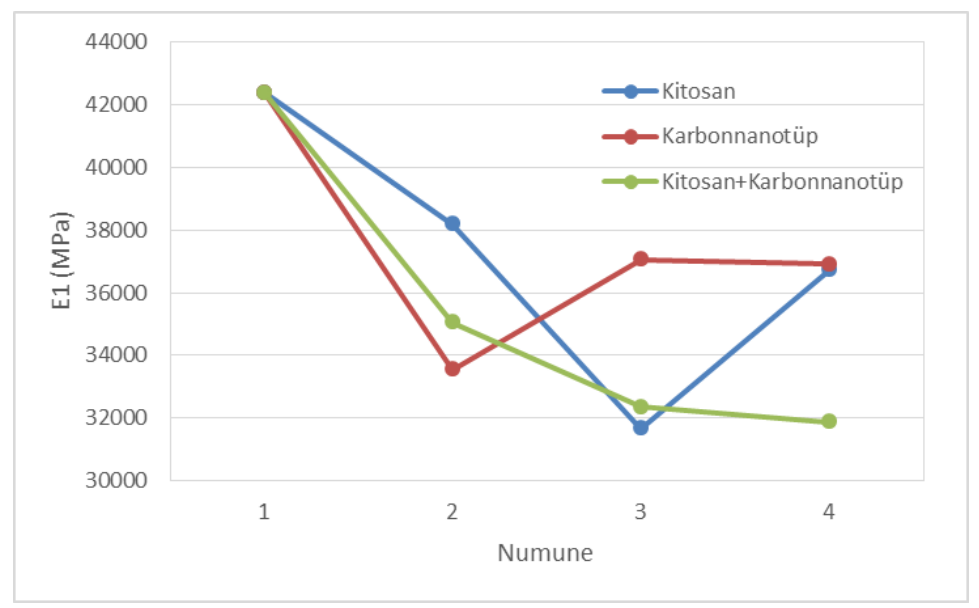

Şekil 9 Fiber doğrultusundaki elastisite modülünün değişimi

Şekil 10 da verilen grafik incelendiğinde fibere dik doğrultudaki (2) elastite modülü değerleri görülmektedir. Grafiğe göre KNT (kabon nanotüp) katkılı plakaların en yüksek değerleri verdiği tespit söylenebilmektedir. Ayrıca katkı oranı arttıkça hibrit kompozitlerin değerlerinin oldukça az olduğu görülmektedir. En yüksek değerin \% 0,2 oranında KNT katkılı 6 numaralı plakada meydana geldiği grafikten görülmektedir. En düşük elastite modülü değerinin 8 numaralı plakada olduğu grafiklerden tespit edilmiştir.

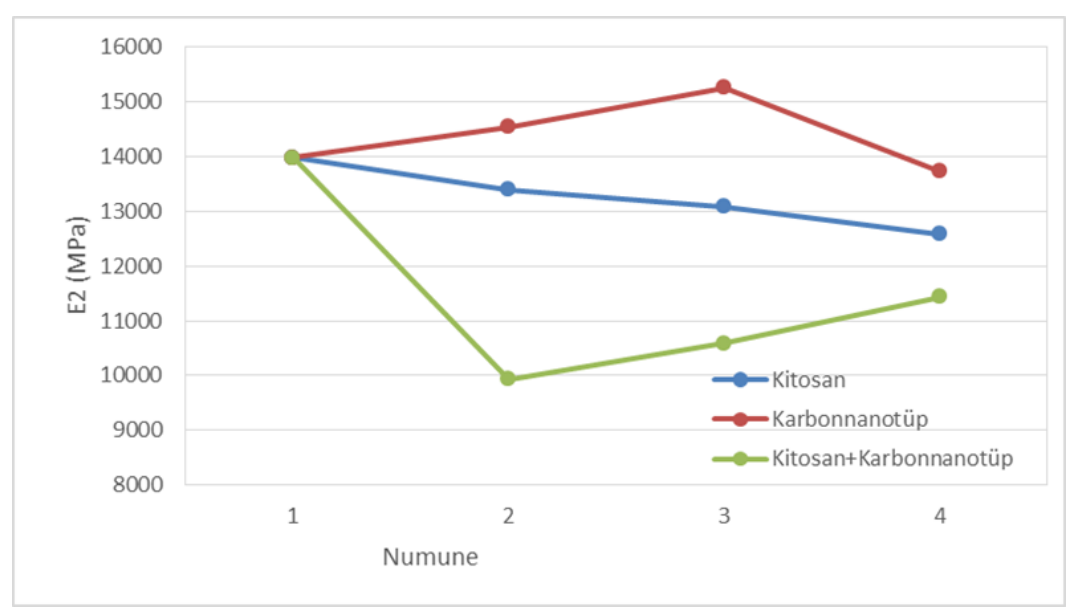

Şekil 10 Fibere dik doğrultudaki elastisite modülünün değişimi

Mekanik testler sonucu elde edilen elastisite modülleri $\left(E_{1}, E_{2}\right.$ ve $\left.E_{x}\right)$ ve poisson oranı değerleri kullanılarak kayma modülü hesaplanmış ve katkı oranlarına göre numunelerin kayma modülü değişimleri Şekil 11 de grafik haline getirilmiştir. Grafik incelendiğinde en yüksek kayma modülü değeri katkısız prepreg olarak imal edilen plaka 1 de olduğu görülmüşsür. Öte yandan plaka 4 te diğer katkılı kompozitlerden daha yüksek kayma modülü değeri elde edilmiştir. En düşük kayma modülü plaka 5 te olduğu 
görülmektedir. Grafik incelendiğinde hibrit plakalar olan KNT+kitosan katkılı plakalarda katkı oranı arttıkça kayma modülü değerinin azaldığı tespit edilmiştir. Karbon nanotüp katkılı plakalar incelendiğinde en yüksek kayma modülü değeri \% 0,2 değerinde KNT katkılı plaka 6 da olduğu tespit edilmiştir.

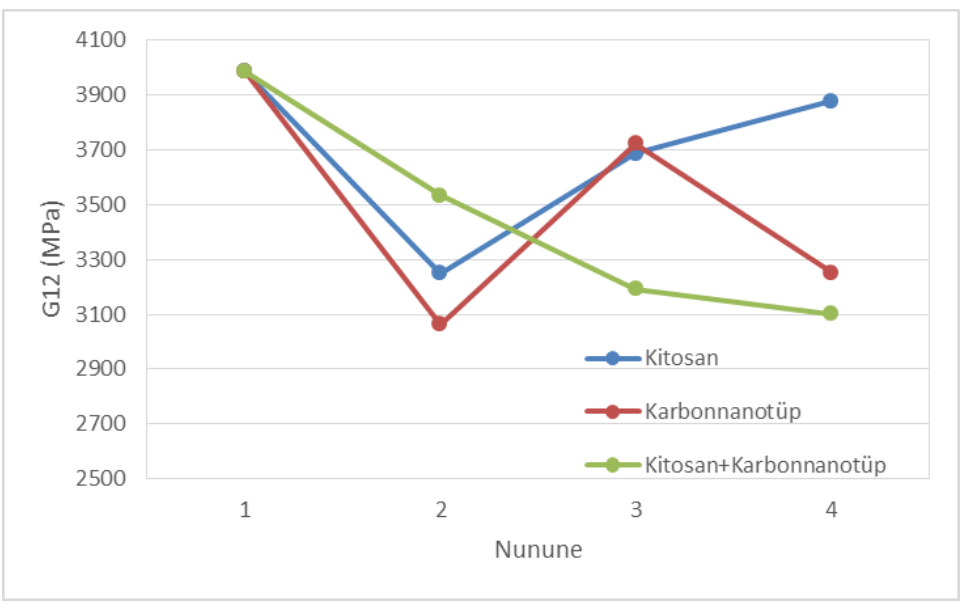

Şekil 11 Katkı oranlarına göre kayma modülü değişimi

Possion oranı değişimleri Şekil 12 de gösterilmiştir. Şekil incelendiğinde en düşük poisson oranı katkısız plaka 1 de oluşmuştur. Hemen hemen tüm plakalarda katkı oranı arttıkça poisson oranı da artmıştır. En yüksek poisson oranına 10 numaralı plaka sahiptir.

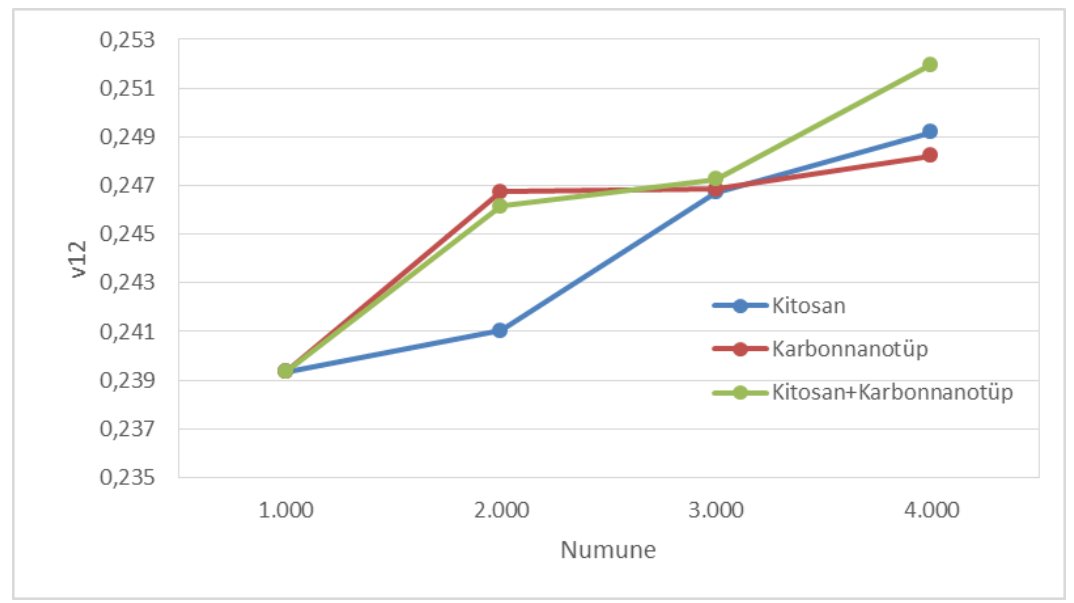

Şekil 12 Poisson orant grafiği

Mekanik özellikler belirlenirken X yönü her zaman fiber doğrultusu alınmaktadır. X yönündeki çekme mukavemetini belirlemek için yapılan testlerin sonucunda Şekil 13 deki grafik meydana getirilmiştir. Grafik incelendiğinde en yüksek çekme mukavemeti katkısız plaka 1 ve kitosan katkılı plaka 2 de meydana gelmiştir. Kitosan oranı arttıkça çekme mukavemeti azalmıştır. En düşük çekme mukavemeti değeri 9 ve 10 numaralı plakalarda olduğu tespit edilmiştir.

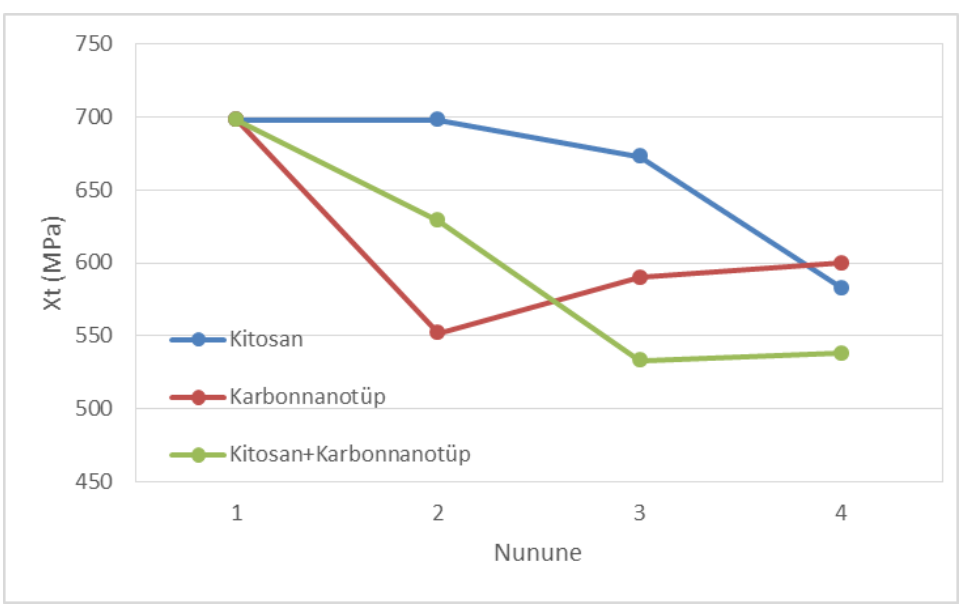

Şekil 13 Fiber doğrultusundaki çekme mukavemeti değişimi 
Şekil 14 te basma mukavemeti değerlerindeki değişimler görülmektedir. Grafik incelendiğinde en yüksek basma mukavemeti plaka 8 de meydana gelmektedir. En düşük değer ise plaka 10 da meydana gelmektedir. KNT katkılı plakalar arasında en yüksek basma mukavemeti değeri plaka 6 da meydana gelmektedir.

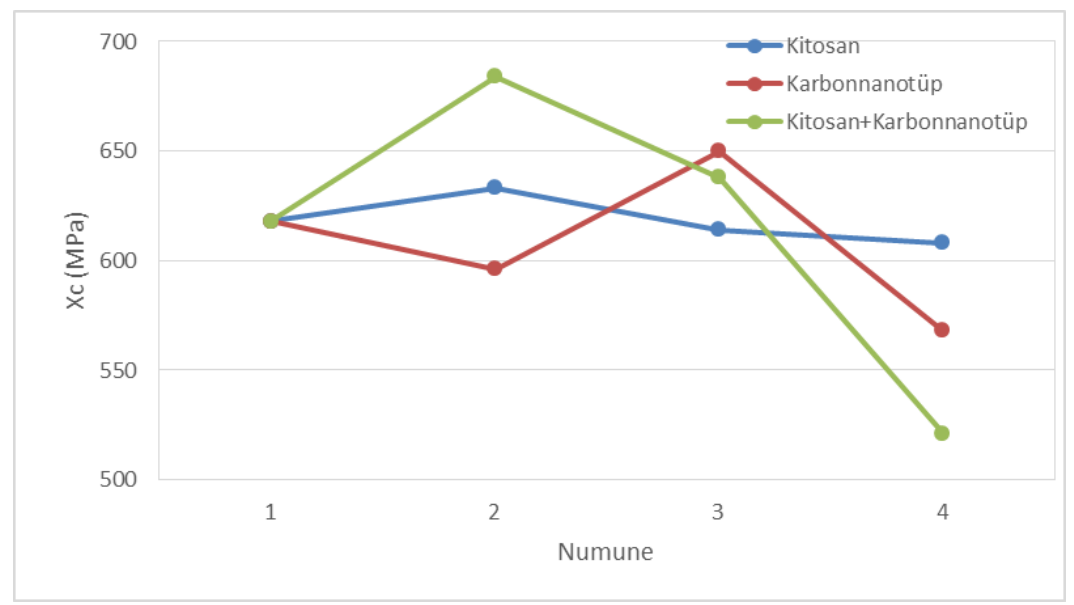

Şekil 14 Fiber doğrultusundaki basma mukavemeti değişimi

Fibere dik doğrultudaki çekme mukavemeti değerleri Şekil 15 te görülmektedir. Grafik incelendiğinde $\% 0,3$ oranında KNT katkılı plaka 7 de en yüksek çekme mukavemeti olduğu görülmektedir. En düşük değer ise plaka 3 te meydana gelmektedir. Her iki katk1 malzemesinin karıştırıldığı hibrit plakalarda ise katkı oranı arttıkça çekme mukavemeti azalmaktadır.

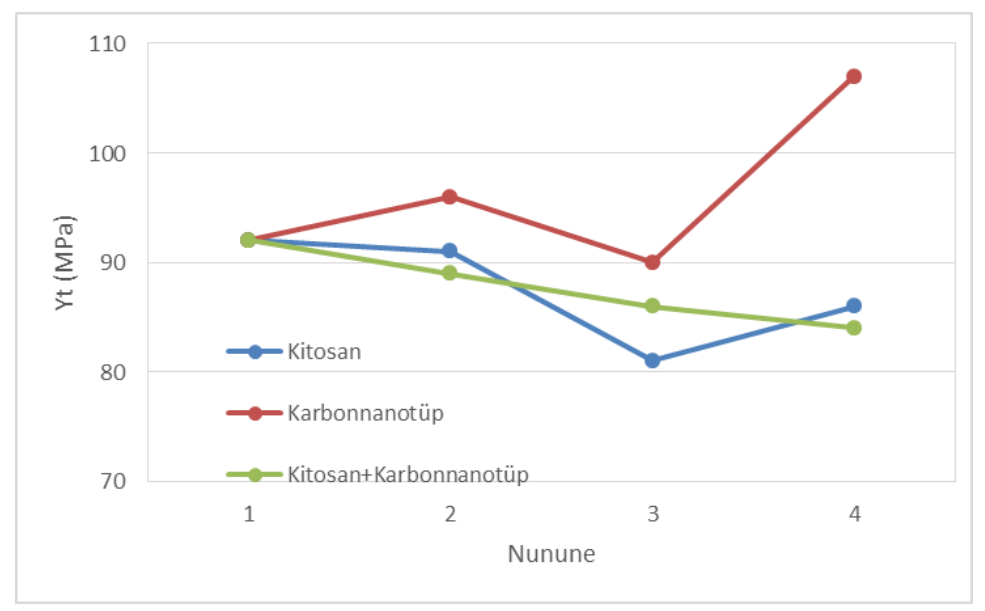

Şekil 15 Fibere dik doğrultudaki çekme mukavemeti değişimi

Fibere dik doğrultudaki basma mukavemetinin değişimi Şekil 16 da verilmiştir. Grafik incelendiğinde en yüksek basma mukavemeti 0,3 oranında KNT katkılı plakada meydana gelmiştir. Plaka 7 de meydana gelen yüksek basma ve çekme mukavemetleri 0,3 oranlı KNT için belirlenen oranlar arasında en sağlıklı sonuç veren oran olduğunu göstermektedir. En düşük basma mukavemeti değeri plaka 2 de meydana gelmiştir.

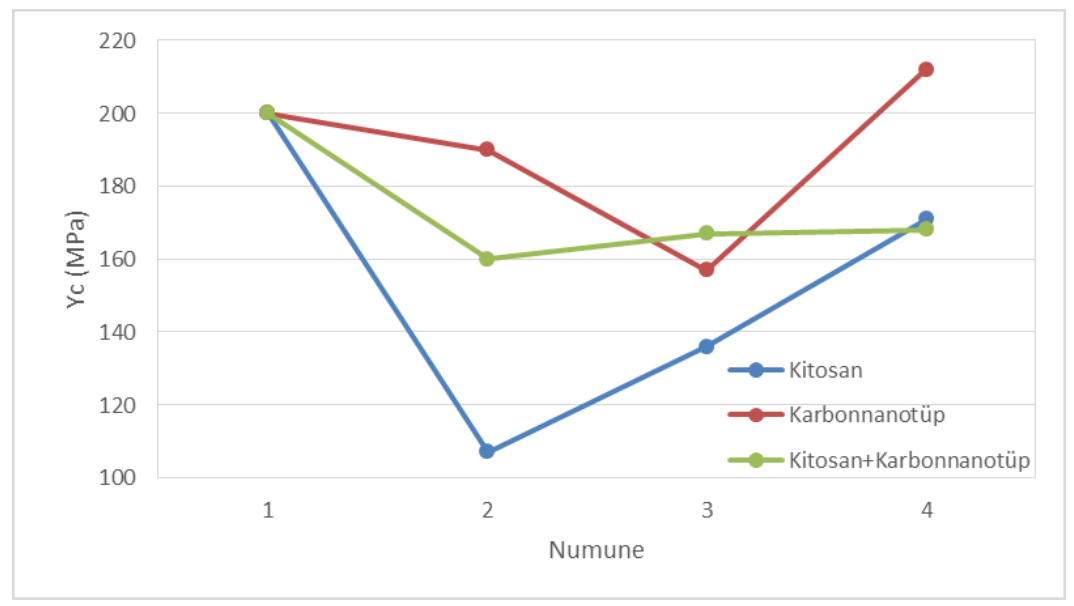

Şekil 16 Fibere dik doğrultudaki basma mukavemetinin değişimi 
Tabakalararası kayma mukavemetini bulabilmek için 2 farklı çekme testi mevcuttur. Tabakaların birbirine ters yüzlerine 2 adet kanal açarak hazırlanan numuneye çekme testi uygulanmış ve elde edilen çekme kuvvetleri iki çentik arası yüzey alanına oranlanarak tabakalararası kayma mukavemeti değerleri elde edilmiştir. Elde edilen kayma mukavemeti değerleri Şekil 17 de grafik haline getirilmiştir. 2 tür katkının da kullanıldığı ve \% 0,3 KNT katkılı kompozit numunelerde tabakalararası mukavemetin oldukça az olduğu tespit edilmiştir. Plaka 1 ile \%0,1 ve 0,2 KNT katkılı kompozit plaklarda en yüksek kayma mukavemeti değerleri elde edilmiştir. Ayrıca grafik irdelendiğinde oluşan kayma mukavemeti değerlerinin oldukça az olduğu tespit edilmiştir.

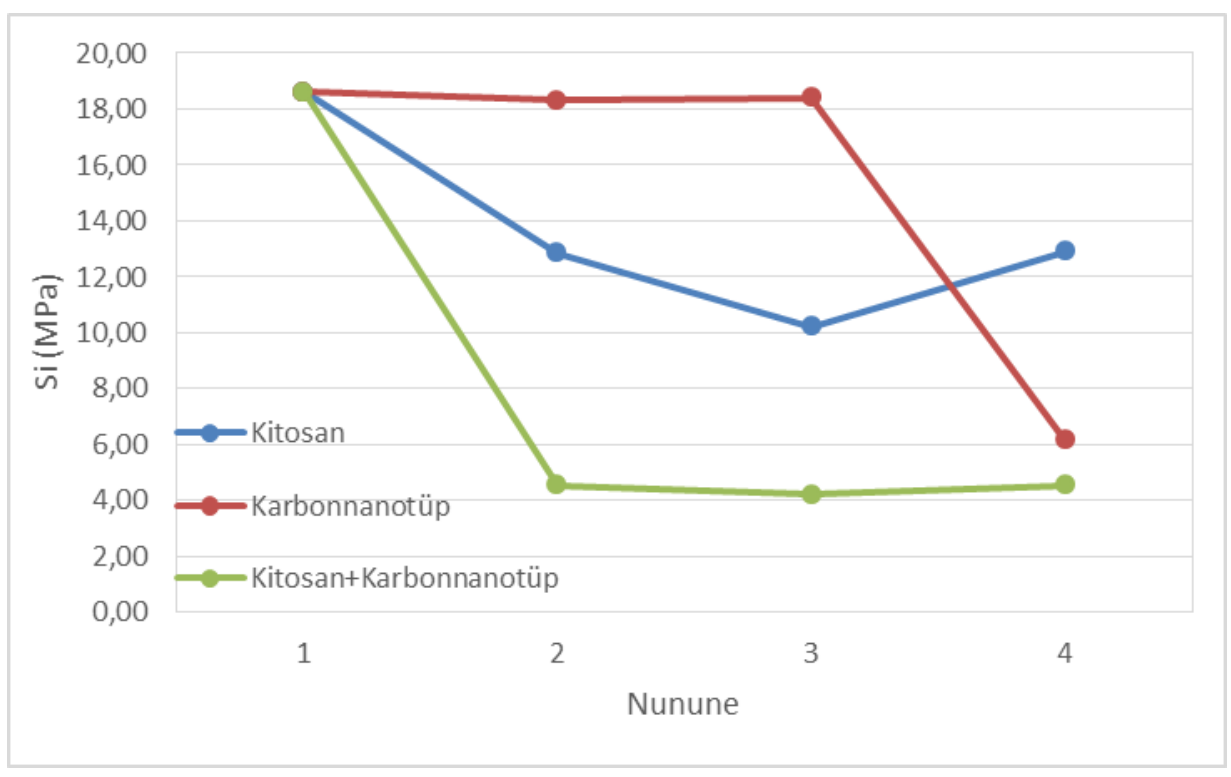

Şekil 17 Tabakalararası kayma mukavemeti değişimi

\subsection{Yaprak Yayın Modellenmesi ve Nümerik Analizleri / Modelling and Numerical Analyzing of Leaf Spring}

Mekanik testler sonucu elde edilen özellikler nümerik analizlerde malzeme özellikleri olarak kullanılmıştır. ANSYS programı kullanılarak yapılan analizler ACP PRE\&POST alt programında modellenip analiz edilmiştir. Mekanik özellikleri belirlenen malzemeye ait geometri katı modelleme programı ile modellenerek Şekil 18 deki gibi kabuk halde ACP Pre programına atılmıştır.

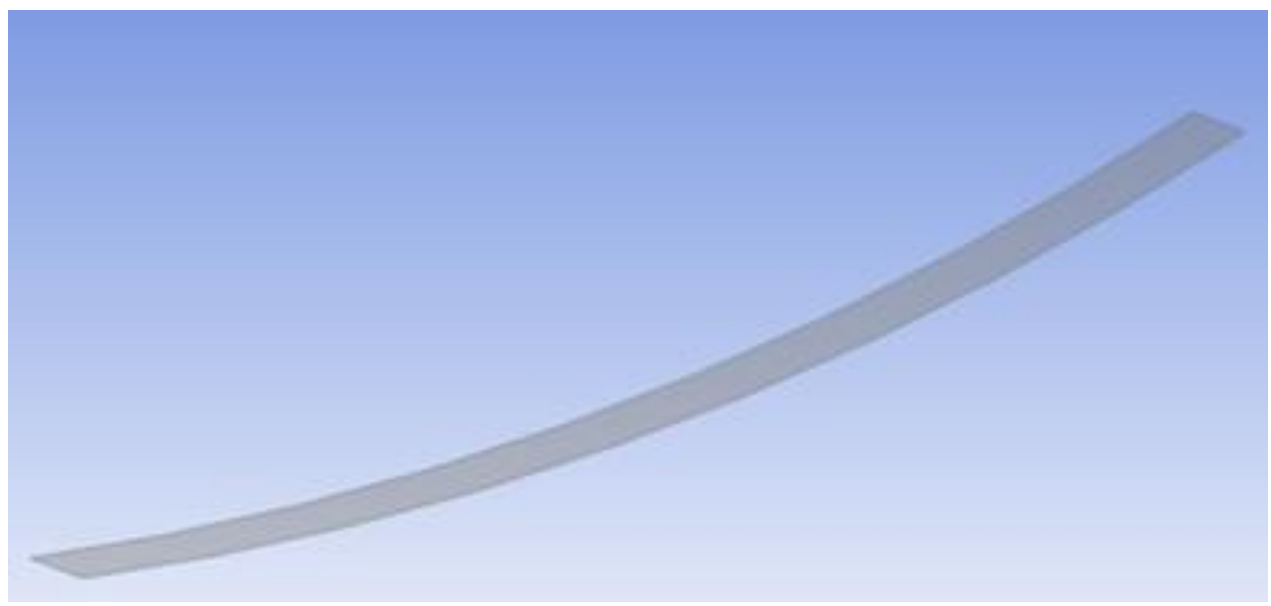

Şekil 18 Kabuk (Shell) modellenmiş yaprak yay

Modellemede kullanılan yay ölçüleri kalınlık t=12 mm, boy L=700 mm, genişlik b=60 mm'dir. Kalınlık olan $12 \mathrm{~mm}$ değeri ACP Pre programının setup kısmında kumaş kalınlığı 0,2 mm şeklinde belirlenmiş ve tabaka sayısı 60'tır. Kabuk modele kaba mesh olarak $3 \mathrm{~mm}$ boyutunda mesh atılarak setup kısmına geçilmiştir.

Nümerik analizler 5 farklı tabaka dizilimi ile 1000 N, 2000 N, 3000 N ve 3750 N yükler altında 10 farklı kompozit numunenin malzeme özellikleri kullanılarak icra edilmiştir. Maksimum $3750 \mathrm{~N}$ luk yük uygulanmasının nedeni, hâlihazırda kullanılmakta olan hafif ticari bir aracın net ağırlığı 2000 kg olup azami yüklü ağırlığı 3500 kg gelmektedir. Aradaki fark istiap haddi 1500 kg'dır. Bu değer 2 arka dingile bölünerek $750 \mathrm{~kg}$ olarak belirlenmiştir. Yayın yarım yaprak yay olarak modellenmesi sebebiyle mevcut değerinde yarısı alınarak analizler en yüksek bu değer üzerinden yapılmıştır. ACP PRE, statik yapılar ve ACP POST programının analiz için düzenlenmiş birbiri ile ilişkisi Şekil 19 da gösterilmiştir. 


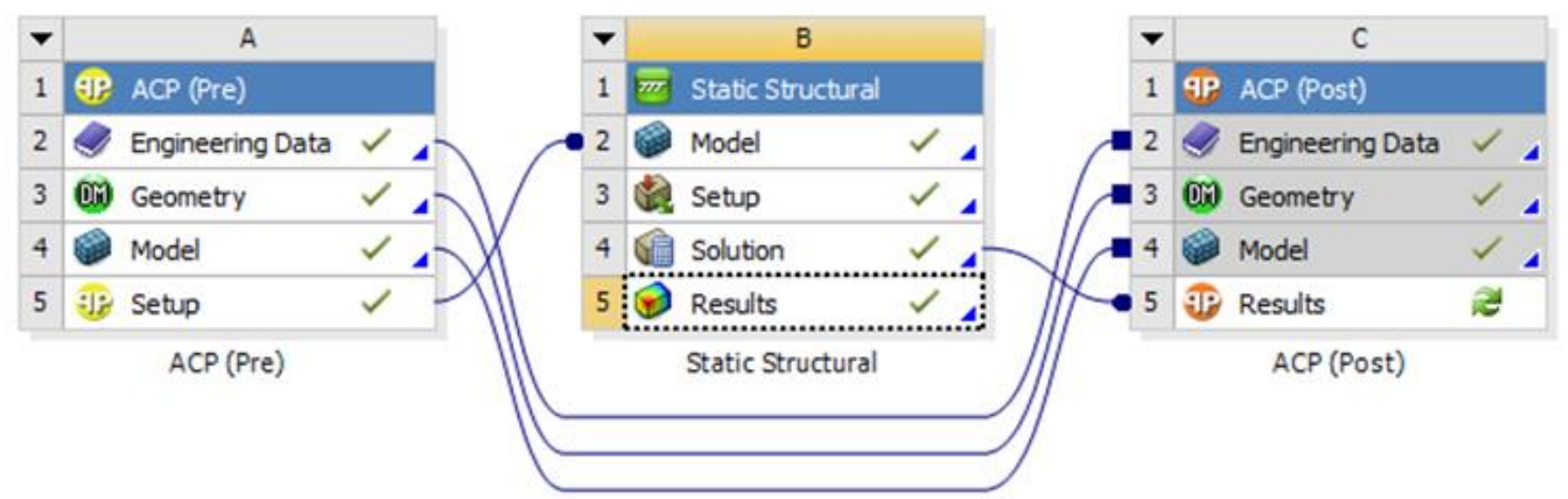

Şekil 19 ACP Pre\&Post ve statik yapular alt programlarının birbiri ile olan ilişkisi

Tabaka dizilimleri her analizde setup kısmına tekrar girilerek değiştirilmiştir. Bu sayede farklı dizilimlerin ve fiber açılarının yaprak yayın mukavemetine etkisi belirlenmiştir. Tabaka dizilimleri şu şekildedir:

1. Tabaka dizilimi (TD1): $\left[0^{\circ}\right]_{60}$

2. Tabaka dizilimi (TD2): $\left[\left[0^{\circ}\right]_{15} /\left[90^{\circ}\right]_{15}\right]_{\mathrm{s}}$

3. Tabaka dizilimi (TD3): $\left[\left[0^{\circ}\right]_{10} /\left[90^{\circ}\right]_{10} /\left[0^{\circ}\right]_{5} /\left[90^{\circ}\right]_{5}\right]_{\mathrm{s}}$

4. Tabaka dizilimi (TD4): $\left[\left[0^{\circ}\right]_{10} /\left[90^{\circ}\right]_{10} /\left[45^{\circ}\right]_{5} /\left[-45^{\circ}\right]_{5}\right]_{\mathrm{s}}$

5. Tabaka dizilimi (TD5): $\left[\left[0^{\circ}\right]_{5} /\left[90^{\circ}\right]_{5} /\left[45^{\circ}\right]_{10} /\left[-45^{\circ}\right]_{10}\right]_{\mathrm{s}}$

Nümerik analizler sonucunda elde edilen değerler çeşitli grafiklere aktarılmış ve böylelikle katkılı ve katkısız yaprak yaylar birbiri ile kıyaslanmıştır. Yapılan analizler 3 nokta eğme testi veya yayın araç şasisine bağlandığındaki çalışma konumu baz alınarak tasarlanmıştır. Bir ucu sabit diğer ucundan düş̧ey Y yönünde ve pozitif doğrultuda kuvvet verilerek analizler gerçekleştirilmiş̧tir. Yapılan analizler sonucu plaka 1 in malzeme özellikleri kullanılarak modellenen yaprak yayın değişken yükler altında ve TD1 de meydana gelen çökme ve gerilmeleri Şekil 20 de görülmektedir.
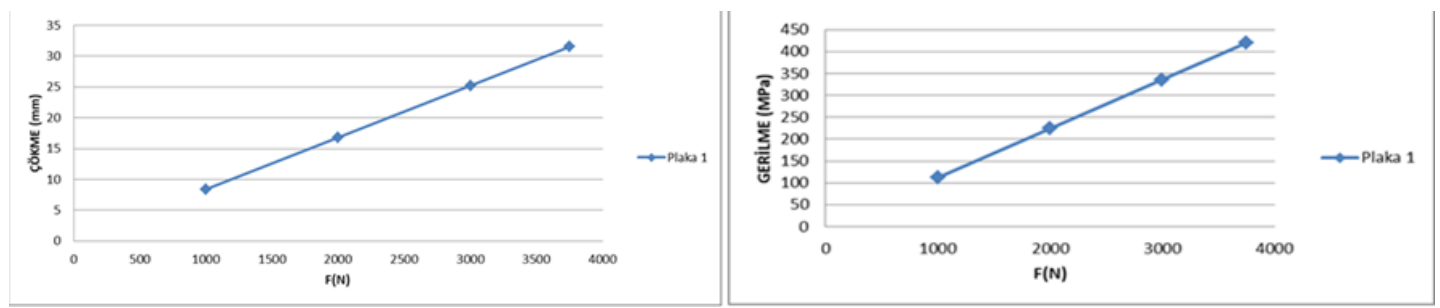

Şekil 20 Katkisız yaprak yaydaki gerilme ve çökme değişimleri

Grafikler incelendiğinde kuvvetteki artış ile çökme ve gerilme değerlerinin paralel olarak arttı̆̆g gözlemlenmiştir. Ayrıca kompozit yayda meydana gelen çökme miktarı yol şartlarından kaynaklanacak olumsuzlukları en aza indirerek yolda seyir halinde konfor sağlayabilecek düzeyde olduğu gözlemlenmiştir.

Şekil 21'de katkısız ve farklı oranlarda kitosan katkılı yayların çökme ve gerilme miktarları karşılaştırılmıştır. $3750 \mathrm{~N}$ kuvvet altında çeşitli tabaka dizilimlerinin yaprak yayın çökme ve gerilme miktarı üzerindeki etkisi belirlenmiştir. Kitosan ilavesi \%2 olan yaprak yayda en fazla çökmenin meydana geldiği gözlemlenmiştir. Katkısız yayın çökme ve gerilme miktarı en az olduğu için kitosan katkısının yayın mukavemetine pek fazla bir katkısının olmadığı söylenebilir. Gerilme değerleri incelendiğinde $3750 \mathrm{~N}$ kuvvet altında en az gerilmenin plaka 3 e ait olduğu görülmektedir.

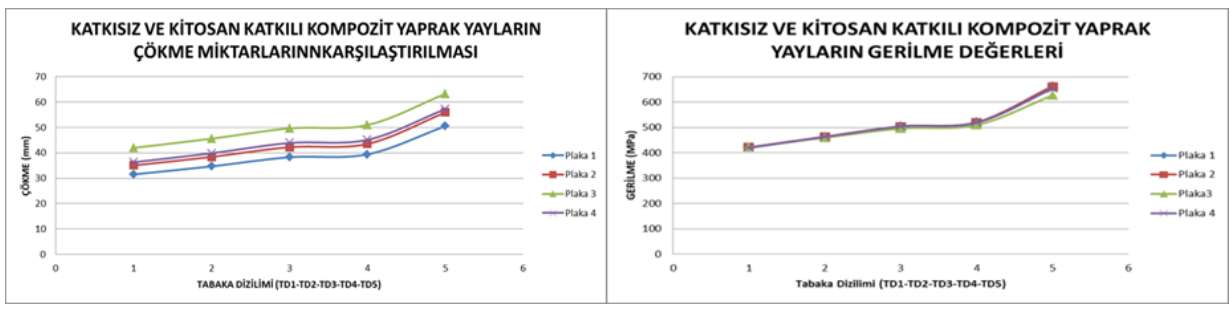

Şekil 21 Kitosan katkll yaprak yayların gerilme ve çökme değişimleri 
Şekil 22 de katkısız ve farklı oranlarda karbon nanotüp (KNT) katkılı yaprak yayların eğilme gerilmeleri ve çökmeleri gösterilmiştir. $\mathrm{Bu}$ değerler incelendiğinde en fazla çökme \%0,1 KNT katkılı yaprak yayda meydana gelmiştir. Katkısız yaprak yay ile katkılı yaprak yaylar kıyaslandığında en az çökmenin meydana geldiği yayın, katkısız yay olduğu grafikte görülmektedir. Katkılı yaylar arasında en az çökme \%0,2 KNT katkılı yaprak yayda meydana gelmiştir. $3750 \mathrm{~N}$ altında gerilme oranları incelendiğinde en az gerilme plaka 6 'da meydana gelmiştir. Tabaka dizilimleri değiştirildiğinde, yaydaki farklı takviye açısı ve sayılarından dolayı gerilme ve çökme miktarları değişmektedir ve belli oranda çökme miktarları artmaktadır.

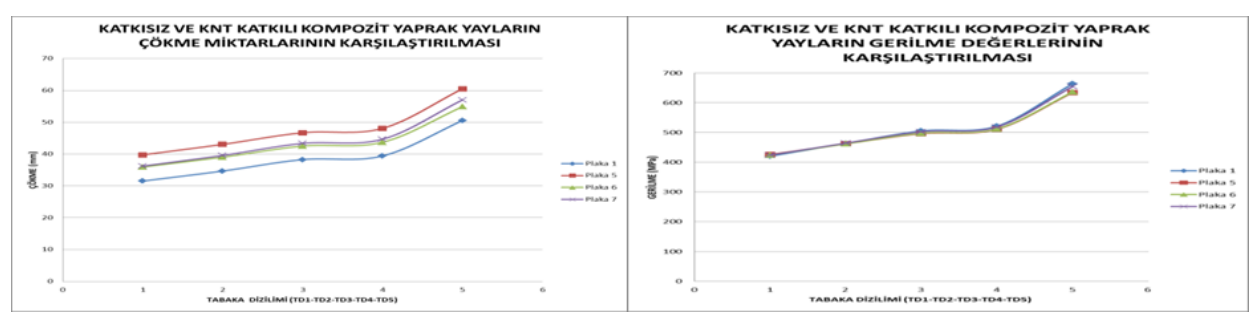

Şekil 22 Karbon nanotüp katkll yaprak yayların gerilme ve çökme değişimleri

Şekil 23'de ise KNT+Kitosan katkılarının beraber ilave edildiği hibrit kompozit yaylar ile katkısız yayda meydana gelen çökme ve eğilme gerilmeleri gösterilmiştir. Elde edilen değerler incelendiğinde fiber takviye yönü $45^{\circ}$ olan ve bu takviye yönündeki tabaka sayısının daha çok olduğu TD5 yayında oluşan eğilme gerilmesi ve çökme değerleri daha büyük olmaktadır. Farklı katkı oranlarına sahip yayların çökmesinde bariz farklar oluşurken eğilme gerilmelerinde pek fazla bir etkisinin olmadığı bu grafikten görülmektedir. Gerilmeler açısından en yüksek gerilme plaka 8 de meydana gelmiştir.

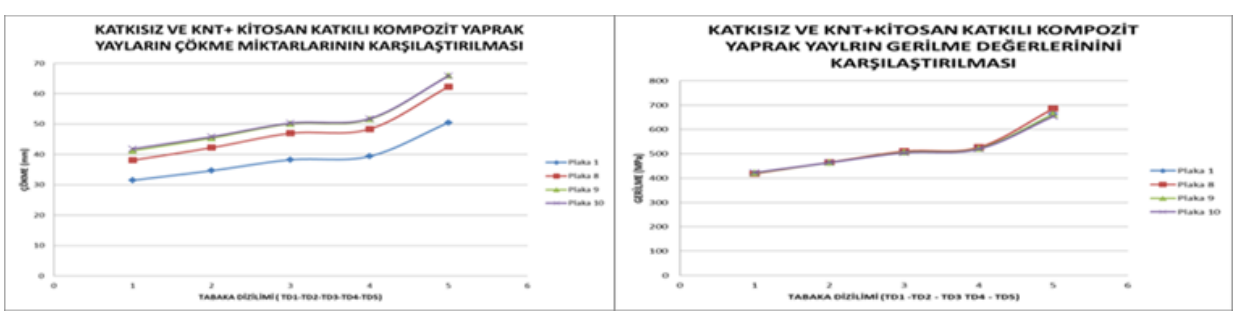

Şekil 23 KNT+ Kitosan katkll yaprak yayların gerilme ve çökme değişimleri

\subsection{Hasar Analizleri / Failure Analysis}

Kompozit yaprak yay nümerik olarak analiz edilirken ACP programından faydalanılmışıtır. ACP programı hem kompozit malzemelerin yapımında hem de analizinde kullanılmıştır. ACP programının Pre versiyonu kompozit yayın modellenmesi için kullanılırken Post kısmı ise yayın analiz ve hasar kriteri gibi Pre kısmında yapılamayan nümerik analizleri barındırmaktadır. Post programı ile Tsai-Wu ve Hashin kriterlerine göre hasar analizleri yapılmıştır. Tsai-Wu kriteri bağlama sabiti olarak "-1" alınmıştır. Hem kriterler hem de yayların tabaka dizilimleri birbiri ile kıyaslanmıştır. $3750 \mathrm{~N}$ yük altında plaka 1'in malzeme özellikleri kullanılan katkısız kompozit yaprak yay analiz edilmiştir. Hasar miktarları ile tabaka dizilimleri karşılaştırıldığında en çok hasar miktarının TD5 yaprak yayında meydana geldiği görülmüştür. En az hasar ise TD1 yayında meydana gelmiştir. Şekil 24'te TD1 ve TD5 kompozit yaprak yayların hasar analizleri gösterilmiştir.

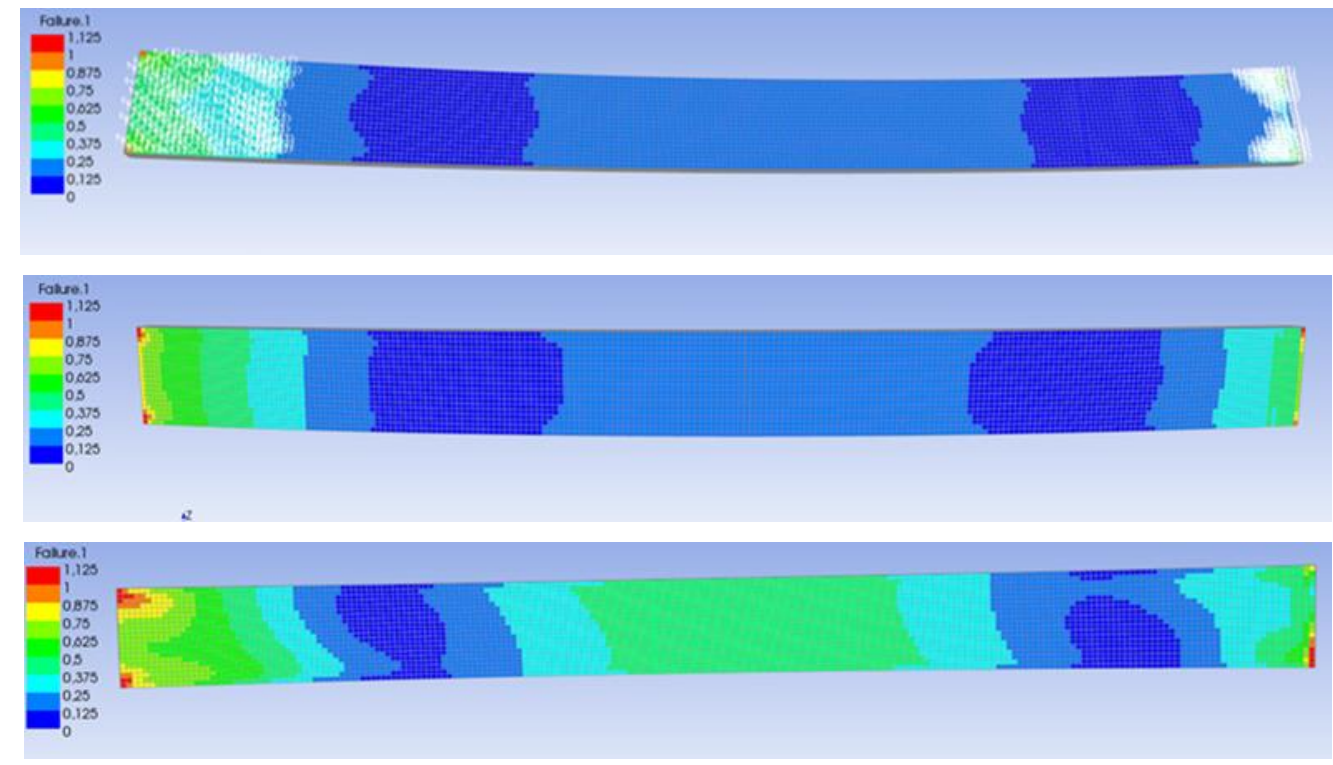




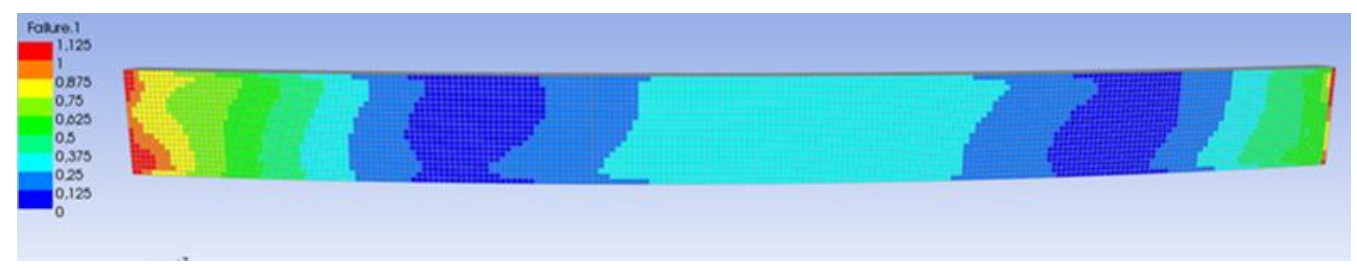

Şekil 24 TD1 ve TD5 kompozit yaprak yaylarındaki hasarlar

Hasar analizi yapılan yaylar her iki kritere göre incelenmiştir. Yapılan analizler neticesinde Tsai-Wu kriterine göre kompozit yaylarda daha fazla deformasyonun meydana geldiği görülmüştür. Bağlama sabiti "-1" alındığı durumlarda Tsai-Wu kriteri, Hashin kriterine göre daha fazla hasarlı bölge göstermektedir. TD5 tabaka dizilimli kompozit yaprak yayda her iki kritere göre de en çok hasarın meydana geldiği Şekil 25 te gösterilmiştir. Yayın uç kısımlarında ve orta bölgelerinde en fazla deformasyonun ve hasarın oluştuğu şekilden görülmektedir.

Tsai-Wu

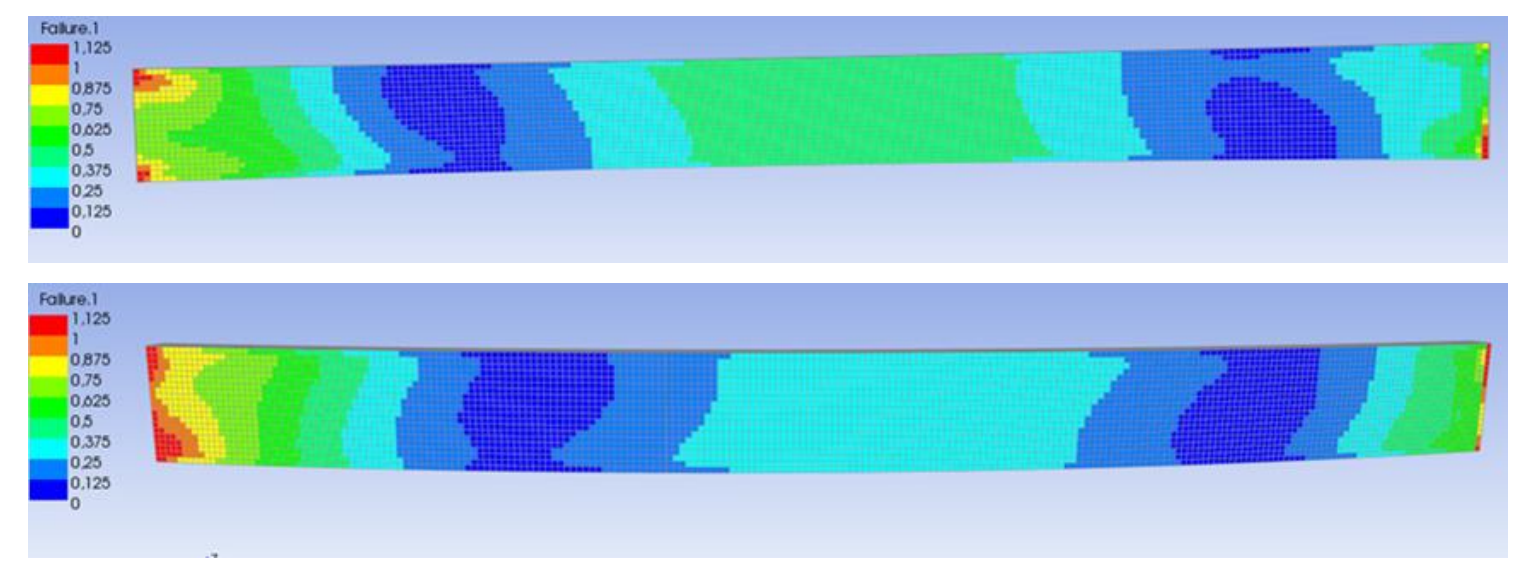

Hashin



Şekil 25 Tsai-Wu ve Hashin kriterine göre hasar analizi yapılmış TD5e göre imal edilmiş yaprak yay

\section{Results and Discussion / Bulgular ve Tartışma}

\subsection{Results / Bulgular}

Yapılan çalışmadan elde edilen bulgular şu şekildedir;

- Kompozit malzemelerde kullanılacak reçine ve katkılar kumaş miktarına göre yoğunluk gösterdiği için kompozit numunelerin mukavemetine doğrudan etkisi olmaktadır.

- Tabaka dizilimleri açısından tek yönlü fiber takviyeli kompozit yayın tercih edilmesi yaprak yayın çalışma prensibinden dolayı daha uygun olacaktır.

- Çökme miktarının ve eğilme gerilmesinin düşük olması nedeniyle kompozit yaprak yaylar hafif ticari araçlar veya günlük araçlarda kullanılmasının uygun olacağı yapılan analizler çerçevesinde tespit edilmiştir. 
- Bağlama sabitinin değeri göz önüne alındığında Tsai-Wu kriteri, Hashin kriterine oranla daha büyük deformasyon göstermektedir.

\subsection{Discussion / Tartışma}

Yapılan çalışmadan elde edilen bulgulara göre, kullanılacak olan reçine miktarı eğer katkı maddesi de kullanılacak ise kumaş miktarına göre tekrar ayarlanmalıdır. Çünkü katkı oranındaki artışın reçinenin akışkanlığı ve yoğunluğuna etkisi kumaşa sürülmesi esnasında gözlemlenebilmektedir. Ayrıca karıştırma yöntemi olarak ultrasonik yöntem kullanıldığı takdirde yoğun katkı oranı karışımın çabuk ısınmasına sebep olup reçinenin kürlenmesine veya mevcut reçinenin uzun süre sirkülatörde kalması durumunda donmasına neden olmaktadır. Bu da reçinenin sürülmesini güçleştirmektedir.

Yapılan diğer kompozit yaprak yay çalışmaları incelendiğinde yoğun olarak kompozit yaprak yayın yatay yönü ile fiber yönünün aynı seçildiği görülmüştür. Bu çalışmadan elde edilen bulgularda buna paralel olup, yaprak yayın araç şasisi altında bağlandığı ve sabitlendiği duruma en uygun tabaka diziliminin yayın boyuna ekseni ile kumaşın fiber yönünün aynı olduğu dizilimlerdir.

Mevcut çalışmalara nazaran bu çalışmada analiz edilen kompozit yaylarda daha fazla çökme meydana geldiği gözlemlenmiştir. Bunun öncelikle yayın yarım olarak modellenip analiz edilmesi sebep gösterilebilir. Öte yandan analiz şartları bakımından da diğer çalışmalardan farklı oluşu bu tartışmaya neden olmuştur. Yayın analizi esnasında göz diye isimlendirilen ve yayın şasiye bağlanması için kullanılan ara parçaların olmayışı da gerilme miktarına doğrudan etki ettiği söylenebilir.

\section{Conclusions and Recommendations / Sonuçlar ve Tavsiyeler}

- KNT miktarının belli bir orandan sonra artırılmasının cam elyaf/epoksi plakların mukavemetine olumsuz etkide bulunduğu gözlemlenmiştir. Kitosan katkısının plakaların mekanik özelliklerinde herhangi bir iyileştirme yapmadığı gözlemlenmiştir. Katkı malzemelerinin miktarının arttırılması reçine karışımında yoğunluğa sebep olduğu için kullanılacak kumaş miktarına uygun oranda katkı maddesi kullanılması mekanik testlerde sağlıklı sonuçlar alınmasına sebep olacaktır. Yapılan mekanik testler her iki katkı maddesinin karıştıııldı̆̆ı durumlarda sağlıklı sonuçlar alınamadığını göstermektedir.

- Farklı tabaka dizilimlerinin denendiği analizler incelendiğinde TD1 diğer tüm dizilimlerden daha iyi sonuç vermiştir. Bunun sebebi ise yaprak yayın çalışma koşulu, yükün etki ettiği yer nedeniyle yayın yatay yönüne paralel fiber takviye açıları bu şartlara en uygun olduğu için en sağlıklı sonuçlar TD1 de elde edilmiştir. Analizler $0^{\circ}$ fiber takviye açısının kompozit yaprak yaylara en uygun fiber takviye açısı olduğunu göstermektedir.

- Katkılı kompozit yaprak yayların katkı maddesi ve oranı ne olursa olsun bu analiz şartlarında katkısız kompozit yaprak yaydan daha az dayanıklı olduğu gözlemlenmiştir. Fakat katkılı ve katkısız kompozit yaprak yayların gerilme oranları birbirine oldukça yakındır. KNT ve Kitosan katkılarının yayda oluşan eğilme gerilmesine etkisi oldukça azdır. Katkı maddelerinin reçine içine homojen dağılabilmesi için kullanılan ultrasonik karıştırıcı katkı miktarı arttıkça etkili bir karışım hazırlamakta zorlandığı için yoğun katkı oranları zayıf sonuçlar vermiştir.

- Yapılan hasar analizleri, $3750 \mathrm{~N}$ kuvvet altında katkısız kompozit yaprak yayın hasarı üzerine tabaka dizilimlerinin etkisinin büyük olduğunu göstermiştir. Tabaka dizilimleri yayın boyuna ekseni ile yaptığı farklı takviye açı durumları hasar oranı artırmaktadır. Tsai-Wu kriteri “-1” bağlama sabiti alındığı durumda Hashin kriterinden daha yüksek şiddette hasar sonuçları vermektedir. TD5 incelendiğinde Tsai-Wu kriterinin yaprak yay üzerinde daha yoğun hasar noktaları oluşturduğu gözlemlenmiştir. Her iki durumda da yayda daha fazla çökmenin oluştuğu orta bölgesi ve kuvvetin uygulandığı, mesnetlerin konumlandığı uç noktalarda hasar oranı daha fazladır.

- Kompozit yaprak yay ile çelik yaprak yayın kıyaslandığı bu çalışmada en önemli hedef ağırlıktan kazanç olduğu bilinmektedir. Cam elyaf malzemeden yarım şekilde modellene yaprak yay, yarım çelik yaprak yaydan oldukça hafiftir. Yapılan nümerik analizlere göre çelik yaprak yay 8,151 kg gelmekte iken kompozit yaprak yay ise 4,062 kg gelmektedir. Bu da yaklaşı olarak $\% 49,84$ oranında hafiflik sağlandığını göstermektedir. Bu hafiflik sayesinde emisyon oranında azalma, yakıt tasarrufu ve daha yüksek beygir gücüne düşen ağırlık değeri sağlanmıştır.

\section{Acknowledge / Teşekkür}

Bu çalışma, Pamukkale Üniversitesi Bilimsel Araştırma Projeleri Koordinasyon Birimi (BAP) tarafından 2017FEBE052 nolu proje ile desteklenmiş̧ir.

\section{References / Kaynaklar}

[1] Kumar, M. S., Vijayarangan, S., (2007) "Analytical and experimental studies on fatigue life prediction of steel and composite multi-leaf spring for light passenger vehicles using life data analysis", Materials Science, 13 (2), 141-146.

[2] Meatto, FD , ED Pilpel., "Durability Comparison of Fiberglass Monoleaf Hybrid and Multileaf Steel Springs", Paper read at Steering and Suspension Technology Symposium, (1999).

[3] Shokrieh, M. M., Rezaei, D., " Analysis and optimization of a composite leaf spring", Composite structures , 60, (3), 317-325, (2003).

[4] Patunkar, M. M., Dolas, D.R., " Modelling and Analysis of Composite leaf spring under the static load condition by using FEA", International Journal of Mechanical \& Industrial Engineering , 1, (1-2011),1-4, (2011). 
[5] Kumar, S.Y.N.V., Teja, M.V., ” Design and Analysis of Composite Leaf Spring”, Int. J. Mech. Ind. Engg , 2, 1, pp. 2231-2247, (2012).

[6] Venkatesan, M., Devaraj, D.H. , "Design and analysis of composite leaf spring in light vehicle", international journal of modern engineering research, 2, (1), 213-218, (2012).

[7] Narayana, V.L., " Design and Analysis Of Mono Composite Leaf Spring For Suspension in Automobiles", Int. J. Eng. Res. \& Tech , 1, 6, pp.1-13, (2012).

[8] Saini, P., Goel, A., Kumar, D., " Design and Analysis of composite leaf spring for light vehicles", international journal of innovative research in science, engineering and technology, cilt no 2, (5), (2013).

[9] Gopalakrishnan, T., Raja, M., Prakash, V.M.J., Gnanavel, C., ” Design and Fabrication of E-Glass /carbon/graphite epoxy hybrid composite leaf spring", International Conference on Emerging Trends in Engineering Research , 183, (2017).

[10]Thippesh, L., " Fabrication of Hybrid Composite Mono-Leaf Spring with Unidirectional Glass Fibers", Materials Today: Proceedings , 5, 2980-2984, (2018).

[11] Sayer, M., (2009). "Hibrit Kompozitlerin Darbe Davranışlarının İncelenmesi”, Doktora Tezi, Fen Bilimleri Enstitüsü, Denizli. 